Tohoku J. exp. Med., 1968, 94, 385-391

\title{
A Simple Method for Histochemical Identification of Acid Mucopolysaccharides in Cryostat Sections
}

\author{
Yoichiro Sasai and Hiroshi Akiba \\ Department of Dermatology (Prof. Y. Takahashi), \\ Tohoku University School of Medicine, Sendai
}

\begin{abstract}
A simple alcian blue method was presented for identifying individual acid mucopolysaccharides in eryostat sections. This method was based on the precipitation of acid mucopolysaccharides with alcian blue and the subsequent differentiation of individual acid mucopolysaccharides with $\mathrm{MgCl}_{2}$ solution at a critical salt concentration. In spot test and tissue sections, the present method differentiated successfully between hyaluronic acid, chondroitin sulfate and heparin.
\end{abstract}

The identification of individual acid mucopolysaccharides in tissue sections was first developed by Zugibe. ${ }^{1}$ However, the enzyme preparations necessary for the method of Zugibe have not been commercially available.

In 1960 , Scott ${ }^{2}$ found out that different polyanions in a mixture could be selectively precipitated with quaternary ammonium salts by varying the ionic concentration. Attempts have been made since then to apply his principle to tissue sections: the acridine orange method of Saunders; ${ }^{3}$ the ion association-fractionation method of Zugibe and Fink; ${ }^{4}$ the cetylpyridinium-toluidine blue method of Kelly, Bloom and Scott; $;$ and the alcian blue method of Scott and Dorling. ${ }^{6}$ The present paper deals with a simple alcian blue method newly devised for demonstrating acid mucopolysaccharides in cryostat sections.

\section{Materials and Methods}

Specimens of the tongue, sternum and femur-tibial joints of 5-day-old rats were taken immediately post mortem. Human umbilical cords were obtained within 15 minutes after birth. Skin specimens from scleredema adultorum, pretibial myxedema and urticaria pigmentosa were obtained by biopsy.

Small samples of each specimen were frozen in isopentane chilled with dry iceacetone mixture, cut $10 \mu$ in thickness on a cryostat, and mounted on cover slips without adhesive. Sections were dried for 5 minutes in air, and were immersed for 15 minutes in $6 \%$ formalin containing $0.5 \%$ alcian blue (alcian blue formalin). After washed with distilled water, the sections were kept for 20 minutes in $\mathrm{MgCl}_{2}$ solution at concentrations varying between $0.05 \mathrm{M}$ and $1.5 \mathrm{M}$, washed with

Received for publication, November 13, 1967. 
distilled water, dehydrated, cleared and mounted in biolit (Oken Shoji Co., Tokyo). In order to examine the effect of various fixatives, some sections were fixed for 15 minutes in absolute ethanol, $6 \%$ neutral formalin, or $0.5 \%$ cetylpyridinium chloride in $6 \%$ formalin (CPC formalin).

To test the specificity of this procedure, filter paper spotted with purified samples of hyaluronic acid, chondroitin sulfate and heparin was treated as described above.

\section{OBSERVATIONS}

\section{1) Effect of $\mathrm{MgCl}_{2}$ on alcianophilia}

When the sections of human umbilical cord were immersed in distilled water containing no $\mathrm{MgCl}_{2}$, the stroma and the medial layer of the umbilical vessels showed no change in their strong alcianophilia. When the sections were immersed in $\mathrm{MgCl}_{2}$ solution, the alcianophilia of the stroma was markedly reduced by $\mathrm{MgCl}_{2}$ at $0.15 \mathrm{M}$, and disappeared at $0.25 \mathrm{M}$. On the other hand, the alcianophilia of the medial layer diminished with $0.5 \mathrm{M} \mathrm{MgCl}_{2}$, and completely disappeared with 0.7 $\mathrm{M} \mathrm{MgCl}_{2}$. In the sections from scleredema adultorum and pretibial myxedema, the alcianophilia of the dermal interfibrillar substance disappeared at a similar molarity of $\mathrm{MgCl}_{2}$ to that for the stroma in the umbilical cord (Figs. 1 and 2). When the sections of the sternum and the femur-tibial joint were employed, the alcianophilia of the chondrocytes was still observed with $0.65 \mathrm{M} \mathrm{MgCl}_{2}$, but disappeared with $0.7 \mathrm{M} \mathrm{MgCl}_{2}$. Mast cells in rat tongue showed a strong alcianophilia with $\mathrm{MgCl}_{2}$ at $0.6 \mathrm{M}$ (Fig. 3). The alcianophilia slightly reduced by $\mathrm{MgCl}_{2}$ at $0.7 \mathrm{M}$, and completely disappeared at $0.85 \mathrm{M}$. Mast cells in urticaria pigmentosa behaved in exactly the same manner as those in the rat tongue (Figs. 4 and 5).

\section{2) Time dependence of the procedure}

The sections of the human umbilical cord were fixed in alcian blue formalin for $1 / 2$ to 60 minutes, and then immersed in $0.05 \mathrm{M} \mathrm{MgCl}_{2}$ solution for 20 minutes. The alcianophilia of the stroma showed some increase with lapse of fixation time, though the increase after 10 minutes was only slight. When the tongue sections fixed in alcian blue formalin for 15 minutes were immersed in $0.5 \mathrm{M} \mathrm{MgCl}_{2}$ solution for 1 to 60 minutes, the alcianophilia of the mast cells was well differentiated by immersion for 15 minutes or longer.

\section{3) Effect of fixatives on alcianophilia}

The sections of the human umbilical cord were fixed for 15 minutes in the following solutions; absolute ethanol, 6\% neutral formalin, and CPC formalin. After washed with distilled water, they were immersed for 15 minutes in $0.5 \%$ alcian blue solution.

When the sections were fixed in absolute ethanol or $6 \%$ neutral formalin, the alcianophilia of the stroma was patchy, and not so intense as that of the stroma 


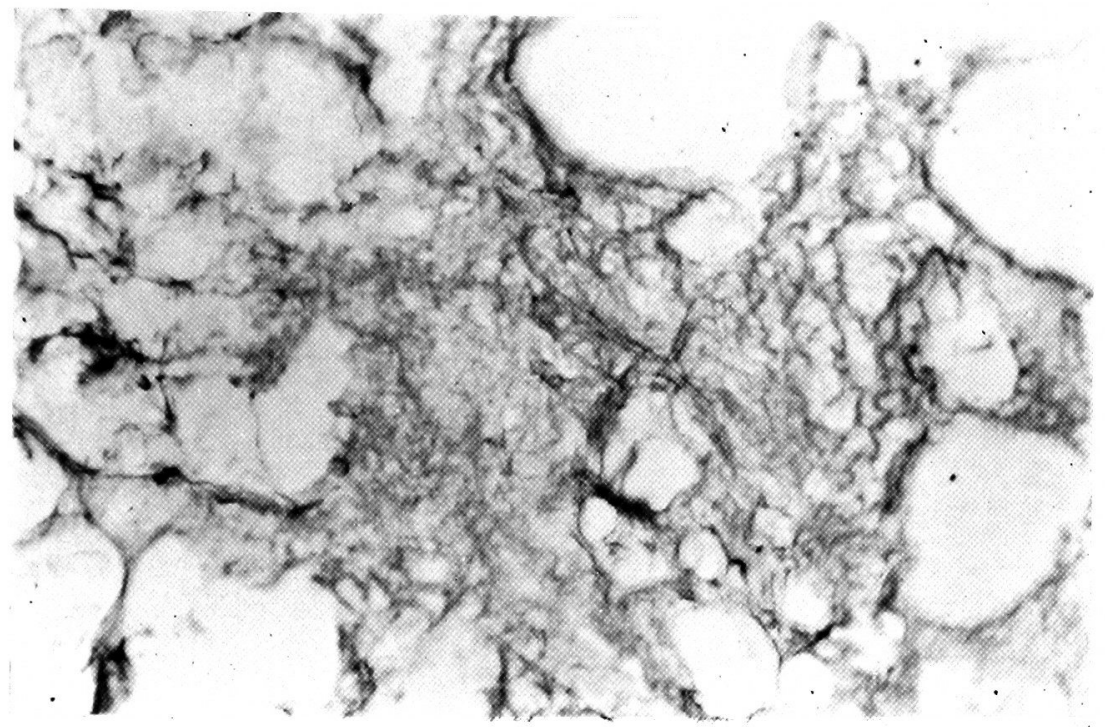

Fig. 1. Scleredema atulforum. Afior im ner.sed in alciun blue formalia, the section was plased in $0.05 \mathrm{M} \mathrm{MgCl}_{2}$ solúion. Dermal intərfibrillar s'lbstance showar a strong alcianophilia. $\times \mathbf{2 8 5}$.

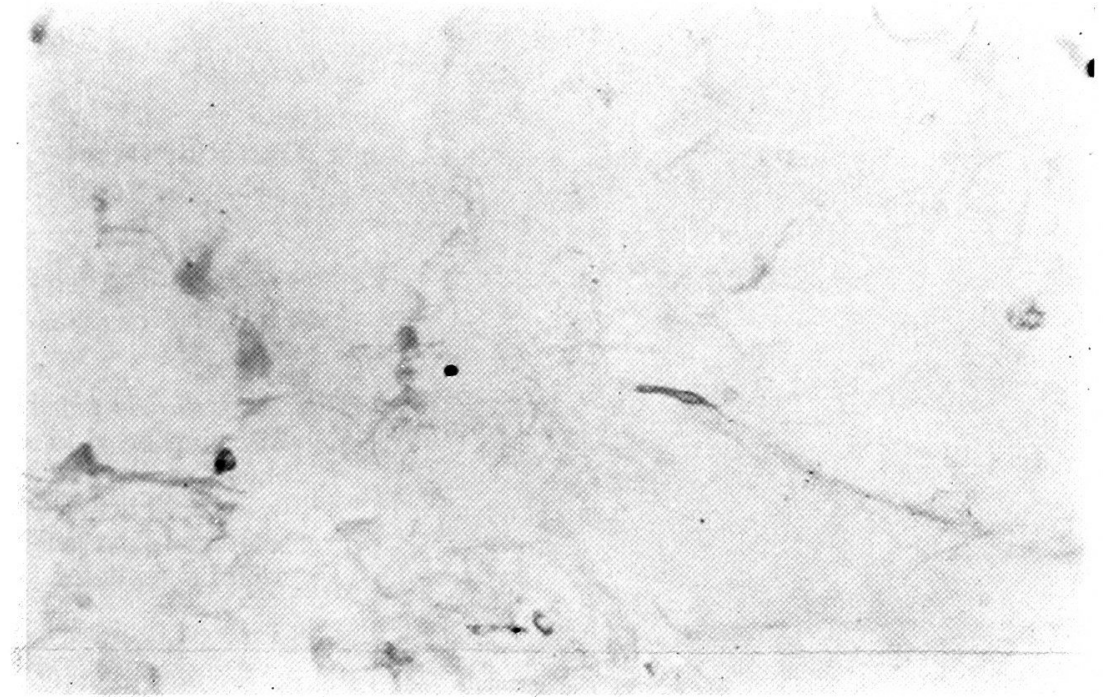

Fig. 2. Scleredema adultorum. Aftor immersed in alcian blue formalin, the section was placed in $0.25 \mathrm{M} \mathrm{MgCl}_{2}$ solution. The alcianophilia of dermal interfibrillar substance completely disappeared. $\times 285$. 


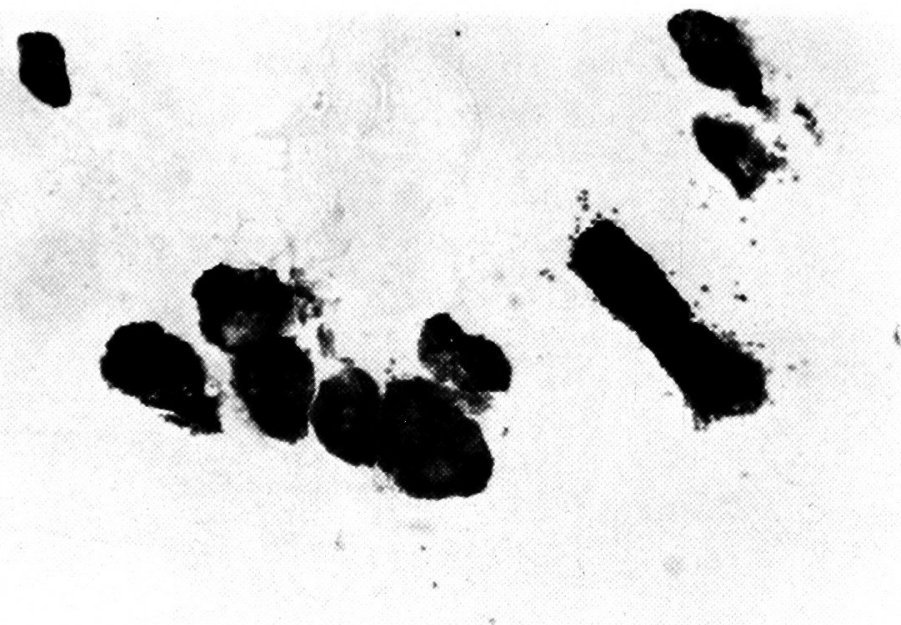

Fig. 3. Rat tongue. After immersed in alcian blue formalin, the section was placed in $0.6 \mathrm{M} \mathrm{MgCl}_{2}$ solution. Mast cells showed a strong alcianophilia. $\times 285$.

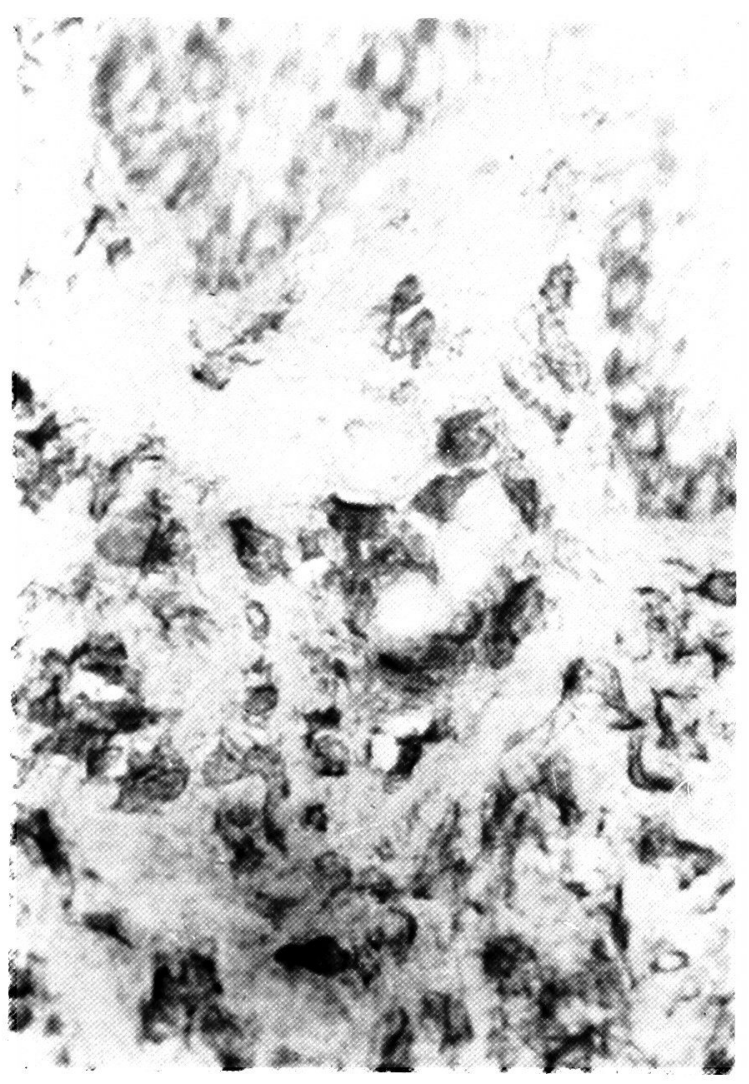

Fig. 4. Urticaria pigmentosa. After immersed in alcian blue formalin, the section was placed in $0.6 \mathrm{M} \mathrm{MgCl}_{2}$ solution. Mast cells were well differentiated. 


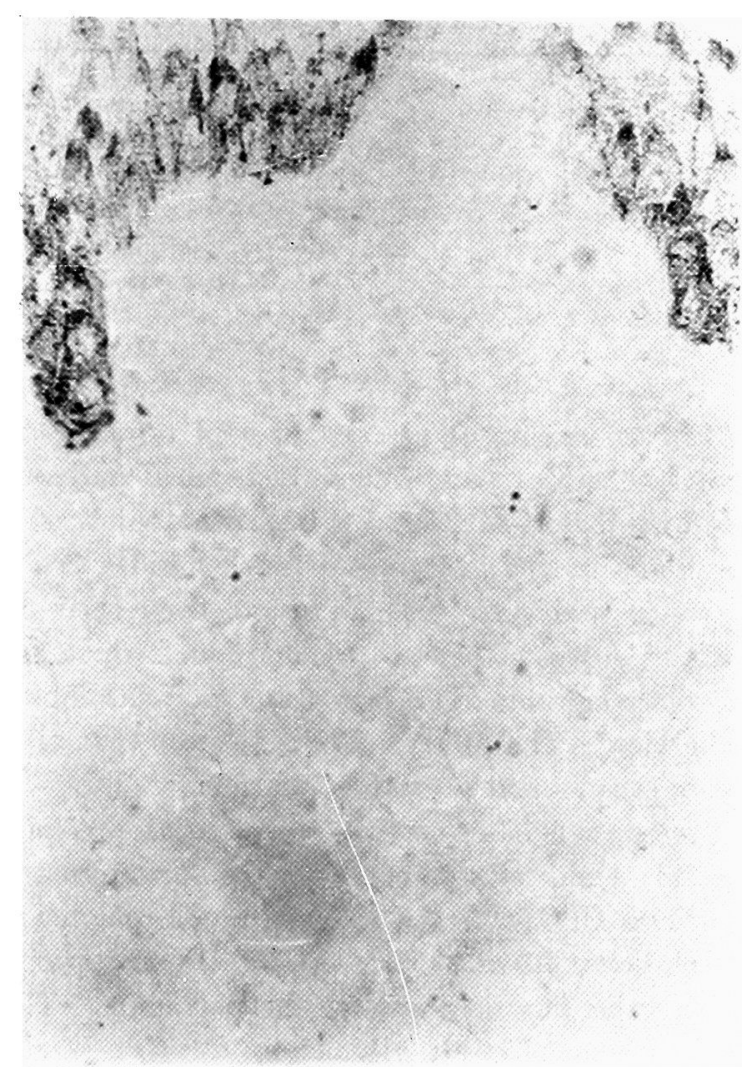

Fig. 5. Urticaria pigmentosa. After immersed in alcian blue formalin, the section was placed in $1.0 \mathrm{M} \mathrm{MgCl}_{2}$ solution. No alcianophilia was found at this salt concentration. $\times 285$.

immersed in alcian blue formalin. In the case of CPC formalin, no alcianophilia was observed.

\section{4) Spot test}

Circular areas on Toyo filter paper (No. 2) were spotted with $0.05 \mathrm{ml}$ of $1 \%$ solution of each acid mucopolysaccharide, and the filter paper was dried in air and kept in alcian blue formalin for 15 minutes. Then, they were washed rapidly with distilled water, and dried in air, then immersed in $\mathrm{MgCl}_{2}$ solution of concentrations varying from 0.05 to $2.0 \mathrm{M}$.

When immersed in distilled water containing no $\mathrm{MgCl}_{2}$, hyaluronic acid and chondroitin sulfate showed a moderate alcianophilia, but the alcianophilia of heparin was not so intense as that of others. $\mathrm{As} \mathrm{MgCl}_{2}$ concentration was raised, the binding of alcian blue to mucopolysaccharides ceased to take place. The alcianophilia of hyaluronic acid disappeared at $0.1 \mathrm{M} \mathrm{MgCl}_{2}$, that of chondroitin sulfate at $0.5 \mathrm{M}$, and that of heparin at $0.6 \mathrm{M}$. These results were shown in Table 1. 
TABLE 1. Alcianophilia of spots containing acid mucopolysaccharides on a filter paper

\begin{tabular}{|c|c|c|c|c|c|c|c|c|c|c|}
\hline \multirow{2}{*}{$\begin{array}{c}\text { Acid } \\
\text { mucopolysaccharides }\end{array}$} & \multicolumn{10}{|c|}{ Molarity of $\mathrm{MgCl}_{2}$} \\
\hline & 0.0 & 0.05 & 0.1 & 0.2 & 0.4 & 0.45 & 0.5 & 0.55 & 0.6 & 0.65 \\
\hline Hyaluronic acid & H & H & \pm & - & - & - & - & - & - & - \\
\hline Chondroitin sulfate & \# & H & \# & it & H & \# & \pm & - & - & - \\
\hline Heparin & + & $H$ & $H$ & H & H & $H$ & $H$ & H & \pm & - \\
\hline
\end{tabular}

\section{Discussion}

Most of the fixatives in current use are directed towards the tissue proteins. Since acid mucopolysaccharides have different chemical and physical properties, they are not affected by these fixatives to the same extent; e.g., alcohol precipitation is reversible. Some of the acid mucopolysaccharides are at least partially extractable with water and also some diffusion from their original sites may possibly occur in the aqueous phase. Alcian blue, which is a water-soluble amphoteric copper phthalocyanin dye, forms a highly insoluble precipitate with acid mucopolysaccharides. ${ }^{7}$ The present results suggest that alcian blue formalin is superior to absolute ethanol and neutral formalin.

The present procedure is based on the differential precipitation theory by Scott. ${ }^{2}$ According to him, all polyanions are precipitated by quaternary ammonium salts such as CPC, and the water-insoluble polyanion-CPC complexes are soluble in salt solutions, provided that the salt concentration is not below the critical one, of which value is a constant for the polyanion. Thus, the polyanion can be identified histochemically by visualizing the CPC moiety bound to the polyanion when tissue sections are treated with CPC solution containing a certain salt at a critical salt concentration. However, no suitable method for demonstrating CPC has been reported. Saunders ${ }^{3}$ used acridine orange in the place of CPC, taking into consideration their similarity in micelle formation. Scott and Dorling, ${ }^{6}$ using spots of polyanion solution on filter paper, found that a specific differentiation of polyanions, based on the critical salt concentration phenomenon, was possible by using any precipitating cation, e.g., alcian blue. In the method developed by Scott and Dorling, ${ }^{6}$ formalin-fixed paraffin-embedded sections are immersed for 4 hours in alcian blue solution containing $\mathrm{MgCl}_{2}$ at various concentrations.

The results of the spot test carried out in the present investigation agreed with those reported by Scott and Dorling; ${ }^{6}$ i.e., hyaluronic acid, chondroitin sulfate and heparin were alcianophilic at $\mathrm{MgCl}_{2}$ concentrations lower than $0.1,0.5$, and 0.6 M, respectively. Furthermore, sections of tissues known to contain each of acid mucopolysaccharides showed a pattern similar to the spot test. Thus, it may well be concluded that the present procedure is useful for the histochemical demonstration of acid mucopolysaccharides in cryostat sections. 


\section{References}

1) Zugibe, F.T. The demonstration of the individual acid mucopolysaccharides in human aortas, coronary arteries and cerebral arteries. I. The methods. $J$. Histochem. Cytochem., 1962, 10, 441-447.

2) Scott, J.E. Aliphatic ammonium salts in the assay of acidic polysaccharides from tissues. In: Methods of Biochemical Analysis, vol. 8, edited by D. Glick, Interscience Publishers. New York, 1960, p. 145.

3) Saunders, A.M. Histochemical identification of acid mucopolysaccharides with acridine orange. J. Histochem. Cytochem., 1964, 12, 164-170.

4) Zugibe, F.T. \& Fink, M.L. Two new ion association complexes for use in acid mucopolysaccharide demonstration. J. Histochem. Cytochem., 1962, 10, 683.

5) Kelly, J.W., Bloom, G.D. \& Scott, J.E. Quaternary ammonium compounds in connective tissue histochemistry. I. Selective unblocking. J. Histochem. Cytochem., 1963, 11, 791-798.

6) Scott, J.E. \& Dorling, J. Differential staining of acid glycosaminoglycans (mucopolysaccharides) by alcian blue in salt solutions. Histochemie, 1965, 5, 221-233.

7) Scott, J.E., Quintarelli, G. \& Dellovo, M.C. The chemical and histochemical properties of alcian blue. I. The mechanism of alcian blue staining. Histochemie, 1964 . 4, 73-85. 